\title{
The protective effect of chlorogenic acid on bovine mammary epithelial cells and neutrophil function
}

\author{
X. X. Gong, X. S. Su, K. Zhan, and G. Q. Zhao' \\ Institute of Animal Culture Collection and Application, College of Animal Science and Technology, Yangzhou University, Yangzhou 225009, China
}

\section{ABSTRACT}

Chlorogenic acid (CGA) is the ester of caffeic acid and quinic acid and plays an important role in antibacterial activity and anti-inflammatory properties. The objective of this study was to examine the effects of CGA on the growth of Staphylococcus aureus and the mRNA levels of the genes encoding the inflammatory response cytokines, $\kappa$-casein, and neutrophil function in bovine mammary epithelial cells (BMEC) exposed to $S$. aureus. Chlorogenic acid has important antibacterial, antioxidant, and anti-inflammatory functions; however, the effect of CGA on BMEC and neutrophils exposed to $S$. aureus has not been investigated previously. Our results demonstrated that 10,20 , and $30 \mu \mathrm{g} / \mathrm{mL}$ CGA had no cytotoxic effects on BMEC in culture, and that $20 \mu \mathrm{g} / \mathrm{mL}$ CGA enhanced the viability of BMEC exposed to $S$. aureus, whereas $30 \mu \mathrm{g} / \mathrm{mL}$ CGA reduced $S$. aureus growth after $9 \mathrm{~h}$ compared with controls. The rate of $S$. aureus invasion into BMEC was also attenuated by $30 \mu \mathrm{g} / \mathrm{mL}$ CGA compared with controls, whereas this treatment led to reduced abundance of $I L 6$, IL8, and TLR2 mRNA in S. aureus-exposed BMEC. Migration of bovine polymorphonuclear leukocytes was significantly decreased in $S$. aureus-exposed BMEC with 10 and $20 \mu \mathrm{g} / \mathrm{mL}$ CGA treatment when compared with $S$. aureus treatment alone. In addition, incubation with 20 or $30 \mu \mathrm{g} / \mathrm{mL}$ CGA enhanced the phagocytic ability of polymorphonuclear leukocytes compared with the control group. Importantly, levels of $\kappa$-casein were enhanced by treatment of $S$. aureus-exposed BMEC with CGA. Our results suggest that the use of CGA may be a potent therapeutic tool against bovine mastitis caused by $S$. aureus.

Key words: chlorogenic acid, Staphylococcus aureus, bovine mammary epithelial cells, inflammatory response

Received December 21, 2017.

Accepted June 30, 2018.

${ }^{1}$ Corresponding author: gqzhao@yzu.edu.cn

\section{INTRODUCTION}

Mastitis, an inflammation of the mammary gland, is a serious infectious disease triggered in cattle by infection with bacteria, such as Staphylococcus aureus or Escherichia coli (Thompson-Crispi et al., 2014; Gao et al., 2017), and results in decreased milk production and quality (Bar et al., 2008). The inflammatory response to bovine mastitis caused by $S$. aureus infection is often slow, and the infection frequently becomes persistent (Schukken et al., 2011; Petzl et al., 2018). The high pathogenicity of $S$. aureus is meditated via pathways that allow it to evade host innate immune defenses (Spaan et al., 2013; Graves et al., 2010; Xu et al., 2013), which consist of 3 major effectors mechanisms: antimicrobial peptides and enzymes, the complement system, and phagocytes (Medzhitov and Janeway, 2000; Rooijakkers et al., 2005). Furthermore, S. aureus virulence factors can affect the levels of specific immune-modulating proteins (Rooijakkers et al., 2005). Moreover, infection with methicillin-resistant $S$. aureus, which is resistant to the majority of antimicrobial agents, is a serious health hazard (Li et al., 2012), and methicillinresistant $S$. aureus infections have been observed in cases of bovine mastitis (Devriese et al., 1972). Hence, alternative approaches aimed at resolution of bovine mastitis caused by $S$. aureus are required.

Previous research efforts have focused on the extensive development of antimicrobial agents to prevent bovine mastitis caused by $S$. aureus and E. coli (Dias et al., 2013); however, consumer concerns about the development of resistance to antimicrobial agents are growing (Bhattacharyya et al., 2016). In addition, the treatment of bovine mastitis using antimicrobial agents is an increasing threat to human health due to the presence of residues of these agents in milk. Hence, the development of novel, alternative therapies for mastitis caused by $S$. aureus also has the potential to improve milk production and quality.

Chlorogenic acid (CGA) is the ester of caffeic acid and quinic acid and is a natural chemical, present in numerous plants, including tobacco (Wang et al., 2008). The chemical exhibits strong antibacterial activity, can reduce the reactive oxygen species (ROS), and 
has immunoprotective and anti-inflammatory properties (Rice-Evans et al., 1996; Kim et al., 2003; Perrone et al., 2008). A previous study demonstrated that CGA has antioxidant properties and protective effects against ischemia-reperfusion injury in the rat small intestine (Sato et al., 2011). Furthermore, CGA is protective against acute hepatotoxicity triggered by LPS in mice, through reduction of NF- $\kappa \mathrm{B}$ p65 phosphorylation (Xu et al., 2010). Hence, various studies have evaluated the antioxidant and anticarcinogenic effects of CGA in humans and mice; however, to date, no studies have investigated the effects of CGA as an alternative strategy for the treatment of bovine mastitis caused by $S$. aureus. The objectives of our study were to investigate the effects of CGA on the growth of $S$. aureus, the expression of genes involved in the inflammatory response, $\kappa-\mathrm{CN}$ levels after exposure of BMEC to S. aureus, and the responses of bovine neutrophils to CGA.

\section{MATERIALS AND METHODS}

\section{Cell Culture}

Bovine mammary epithelial cells (BMEC) of 3 mid-lactation Holstein cows were obtained from the Institute of Animal Culture Collection and Application, Yangzhou University. These bovine mammary tissues were digested by collagenase type I (Invitrogen, Shanghai, China) for $3 \mathrm{~h}$ and cells were filtered by nylon mesh $(75 \mu \mathrm{m})$ to obtain the BMEC. The BMEC were seeded in DMEM/F12 medium supplemented with $10 \%$ fetal bovine serum, $4 \mathrm{~m} M$ glutamine, $1 \times$ insulin, transferrin, sodium selenite $(10 \mu \mathrm{g} / \mathrm{mL}$ insulin, $5.5 \mu \mathrm{g} /$ $\mathrm{mL}$ transferrin, $0.0067 \mu \mathrm{g} / \mathrm{mL}$ sodium selenite; Invitrogen), $15 \mathrm{ng} / \mathrm{mL}$ epidermal growth factor (Peprotech, Shanghai, China), $1 \mu \mathrm{g} / \mathrm{mL}$ hydrocortisone, and $4 \mu \mathrm{g} /$ $\mathrm{mL}$ prolactin (Sigma-Aldrich, Shanghai, China). Polymorphonuclear leukocytes were obtained as described previously (Garcia et al., 2015) and cultured in RPMI1640 medium supplemented with $5 \%$ inactivated fetal bovine serum and $4 \mathrm{~m} M$ glutamine.

\section{Bacterial Strain and Culture}

Staphylococcus aureus (ACTT29213) were obtained from American Type Culture Collection and cultured in brain heart infusion (BHI) media at $37^{\circ} \mathrm{C}$.

\section{Cytotoxicity Assay}

The cytotoxic effects of CGA on BMEC were determined using the Cell Counting Kit-8 (CCK-8; Dojindo, Shanghai, China), according to the manufacturer's protocol (https://www.dojindo.com/store/p/456-Cell
-Counting-Kit-8.html). The BMEC $\left(5 \times 10^{3}\right.$ cells/well $)$ were seeded into 96-well plates. After $12 \mathrm{~h}$, cells were incubated for further $48 \mathrm{~h}$ with 0 (control group), 10, 20,30, 40 or $50 \mu \mathrm{g} / \mathrm{mL}$ CGA ( $=3)$. Subsequently, $10 \mu \mathrm{L}$ of CCK- 8 reagent was added to cells, followed by incubation at $37^{\circ} \mathrm{C}, 5 \% \mathrm{CO}_{2}$ for $4 \mathrm{~h}$. Absorbance at $450 \mathrm{~nm}$ was then measured in each well using an auto-microplate reader (Thermo Scientific, Shanghai, China).

\section{Cell Viability Assay}

Bovine mammary epithelial cells were seeded into 96 -well plates $\left(5 \times 10^{3}\right.$ cells/well $)$ and $S$. aureus was added after $12 \mathrm{~h}\left(5 \times 10^{3} \mathrm{cfu} /\right.$ well $)$. Cells were then cultured in DMEM/F12 medium in the absence of $S$. aureus and CGA (control group), in the presence of $S$. aureus and absence of CGA (S. aureus group), and in the presence of $S$. aureus and 10,20 , or $30 \mu \mathrm{g} /$ $\mathrm{mL}$ CGA (CGA-treated groups) for $6 \mathrm{~h}(\mathrm{n}=3)$. After incubation, cells were vigorously washed 5 times with $200 \mu \mathrm{L}$ of sterile water and incubated with $100 \mu \mathrm{L}$ of DMEM/F12 supplemented with $10 \mu \mathrm{L}$ of CCK-8 at $37^{\circ} \mathrm{C}$ and $5 \% \mathrm{CO}_{2}$ for $4 \mathrm{~h}$. Absorbance at $450 \mathrm{~nm}$ was then measured in each well using an auto-microplate reader. Cell viability (\%) was calculated as (treatment OD - blank OD)/(control OD - blank OD, where OD $=$ optical density).

\section{S. aureus Growth Assay}

Staphylococcus aureus was seeded into 96-well plates $\left(1 \times 10^{5} \mathrm{cfu} /\right.$ well $)$ in BHI medium supplemented with 0 (control group), 10, 20, or $30 \mu \mathrm{g} / \mathrm{mL}$ CGA $(\mathrm{n}=4)$ at $37^{\circ} \mathrm{C}, 5 \% \mathrm{CO}_{2}$. Absorbance at $600 \mathrm{~nm}$ was then measured for $3,6,9,12$, and $24 \mathrm{~h}$ using an auto-microplate reader.

\section{S. aureus Biofilm Formation Assay}

Biofilm formation was assessed as described previously (Federman et al., 2016). Briefly, S. aureus was seeded into 96 -well plates $\left(2 \times 10^{6} \mathrm{cfu} /\right.$ well $)$ and incubated at $37^{\circ} \mathrm{C}, 5 \% \mathrm{CO}_{2}$ for $24 \mathrm{~h}$. Supernatants were then removed, BHI medium supplemented with 0 (control group), or 10,20 , or $30 \mu \mathrm{g} / \mathrm{mL}$ CGA $(\mathrm{n}=4)$ added, and plates wrapped with Parafilm (Solarbio, Beijing, China) and incubated at $37^{\circ} \mathrm{C}, 5 \% \mathrm{CO}_{2}$ for 36 h. Next, the plates were rinsed 5 times with sterile distilled water, S. aureus fixed with $100 \mu \mathrm{L}$ of methyl alcohol for $15 \mathrm{~min}$, and the supernatant removed. The plates were allowed to dry naturally at room temperature and then treated with $200 \mu \mathrm{L}$ of $0.1 \%$ crystal violet at room temperature for 10 to $15 \mathrm{~min}$. Plates were then rinsed 
5 times, allowed to air dry overnight, and $30 \%$ acetic acid in sterile distilled water $(200 \mu \mathrm{L})$ was then added to each well. Plates were incubated with shaking for 1 $\mathrm{h}$, and the solution in each well transferred to a new 96-well plate. To examine $S$. aureus biofilm formation, absorbance at $540 \mathrm{~nm}$ was measured using an automicroplate reader.

\section{S. aureus Invasion Assay}

To determine the number of $S$. aureus invading BMEC under different conditions, we followed a previously described method (Díaz-Murillo et al., 2016). The BMEC grown in 24-well plates were infected using DMEM/F12 medium containing $S$. aureus $\left(1 \times 10^{5}\right.$ $\mathrm{cfu} /$ well) at a multiplicity of infection of 1 , and treated with 0 (control group), 10, 20, or $30 \mu \mathrm{g} / \mathrm{mL}$ CGA (n $=3$ ) at $37^{\circ} \mathrm{C}, 5 \% \mathrm{CO}_{2}$ for $3 \mathrm{~h}$. Cells were then washed 5 times with sterile PBS. Next, $250 \mu \mathrm{g} / \mathrm{mL}$ gentamicin was added, samples were incubated at $37^{\circ} \mathrm{C}, 5 \% \mathrm{CO}_{2}$ for $1 \mathrm{~h}$, and then washed 5 times with PBS to remove the gentamicin. Cells were lysed with $0.5 \%$ Triton X-100 (Solarbio) for $15 \mathrm{~min}$. The remaining live bacteria were then serially diluted, seeded in BHI agar plates, and colony-forming units were counted. Invasion rate (\%) was calculated as (number of intracellular S. aureus/ number of added $S$. aureus $) \times 100$.

\section{PMNL Chemotaxis Assay}

The BMEC were seeded into 12 -well plates $\left(1 \times 10^{6}\right.$ cells/well). After $12 \mathrm{~h}$, the supernatant was removed and cells washed 3 times with PBS. The $S$. aureus $(1 \times$ $10^{6} \mathrm{cfu} /$ well) was then added and incubated with BMEC for $6 \mathrm{~h}$. Supernatants were then filtered through 0.22 $\mu \mathrm{m}$ sterile filters to collect media containing high levels of the chemoattractant, IL-8. The PMNL suspension $(600 \mu \mathrm{L})$ was seeded into 12 -well plates $\left(3 \times 10^{6}\right.$ cells/ well) and cells pretreated with RPMI-1640 medium containing 0 (control group), 10, 20, or $30 \mu \mathrm{g} / \mathrm{mL}$ CGA $(\mathrm{n}=3)$ at $37^{\circ} \mathrm{C}, 5 \% \mathrm{CO}_{2}$ for $2 \mathrm{~h}$. Next, $500 \mu \mathrm{L}$ of medium containing $I L 8$ was added to the bottom wells of 24-well plates. Chambers (pore size, $5.0 \mu \mathrm{m}$; diameter, $6.5 \mathrm{~mm}$; Corning Inc., Corning, NY) were placed in the top of wells and $100 \mu \mathrm{L}$ of PMNL suspension $\left(5 \times 10^{5}\right.$ cells/chamber) pretreated with different concentrations of CGA was seeded into the chambers. Samples were incubated at $37^{\circ} \mathrm{C}, 5 \% \mathrm{CO}_{2}$ for $1.5 \mathrm{~h}$. Subsequently, chambers were rinsed vigorously 3 times with $100 \mu \mathrm{L}$ of calcium and magnesium-free Hanks' balanced salt solution, and PMNL that had migrated to the bottom wells counted. In addition, another experiment was also performed to evaluate PNML migration using supernatant obtained from $S$. aureus-exposed BMEC with 0 (control group), 10, 20, or $30 \mu \mathrm{g} / \mathrm{mL}$ CGA treatment $(\mathrm{n}=3)$.

\section{PMNL Phagocytosis Assay}

Staphylococcus aureus was preloaded with $5 \mu \mathrm{g} / \mathrm{mL}$ fluorescein isothiocyanate (FITC) at $37^{\circ} \mathrm{C}, 5 \% \mathrm{CO}_{2}$ for 2 h. After preloading, samples were washed 3 times with PBS and stored, protected from light, at $4^{\circ} \mathrm{C}$. Subsequently, PMNL $\left(2 \times 10^{5}\right.$ cells/well $)$ were seeded into 12-well plates and treated with RPMI-1640 medium containing 0 (control group), 10, 20, or $30 \mu \mathrm{g} /$ $\mathrm{mL}$ CGA $(\mathrm{n}=3)$ at $37^{\circ} \mathrm{C}, 5 \% \mathrm{CO}_{2}$ for $2 \mathrm{~h}$. The $S$. aureus preloaded with FITC $\left(2 \times 10^{5} \mathrm{cfu} /\right.$ well $)$ was then incubated with the PMNL at $37^{\circ} \mathrm{C}, 5 \% \mathrm{CO}_{2}$ for 20 min. The mixture was then washed 3 times with PBS and examined by flow cytometry. The PMNL populations were gated by forward and side scatter, and FSC and FL1 channel detection was performed immediately to analyze the phagocytosis of FITC-labeled S. aureus. Data in the gate set for bovine PMNL were collected for 20,000 events per sample, and the percentage fluorescence used as a quantitative index of PMNL response. Intracellular bacteria were distinguished by quenching the extracellular fluorescence with $0.4 \%$ Trypan blue (Solarbio).

\section{Quantitative Real-Time PCR}

For mRNA expression analysis, BMEC were seeded in 6 -well plates $\left(1 \times 10^{6}\right.$ cells/well $)$ and grown at $37^{\circ} \mathrm{C}$, $5 \% \mathrm{CO}_{2}$. Cells were divided into 4 experimental groups: (1) control, DMEM/F12 medium $(\mathrm{n}=3)$; (2) CGA treatment, DMEM/F12 medium containing $30 \mu \mathrm{g} / \mathrm{mL}$ CGA (n = 3); (3) S. aureus treatment, DMEM/F12 medium supplemented with $1 \times 10^{6} \mathrm{cfu}$ of $S$. aureus $(\mathrm{n}$ $=3$ ); and (4) S. aureus with CGA treatment, DMEM/ F12 medium supplemented with both $1 \times 10^{6} \mathrm{cfu}$ of $S$. aureus and $30 \mu \mathrm{g} / \mathrm{mL}$ CGA $(\mathrm{n}=3)$. The $S$. aureus and $S$. aureus with CGA treatment groups were pretreated with $S$. aureus for $6 \mathrm{~h}$. Medium supernatant was removed and cells were washed 3 times with PBS. The control and $S$. aureus treatment groups were further incubated with DMEM/F12 medium for 6 h. The CGA treatment and $S$. aureus with CGA treatment group were further incubated with $30 \mu \mathrm{g} / \mathrm{mL}$ CGA for $6 \mathrm{~h}$. After $6 \mathrm{~h}$, total RNA was isolated from the cultured cells using a TRIzol kit (Tiangen, Beijing, China). Reverse transcription (RT) was performed using an RT Kit (Takara, Beijing, China). The RT reaction mixtures contained $1 \mu \mathrm{g}$ of total RNA and $1 \times$ PrimeScript RT Master Mix (Takara) in a final volume of $20 \mu \mathrm{L}$ and reactions were performed for $15 \mathrm{~min}$ at $37^{\circ} \mathrm{C}$. Reverse transcriptase was inactivated by heating to $85^{\circ} \mathrm{C}$ for 5 
Table 1 Primers for real-time PCR analyses

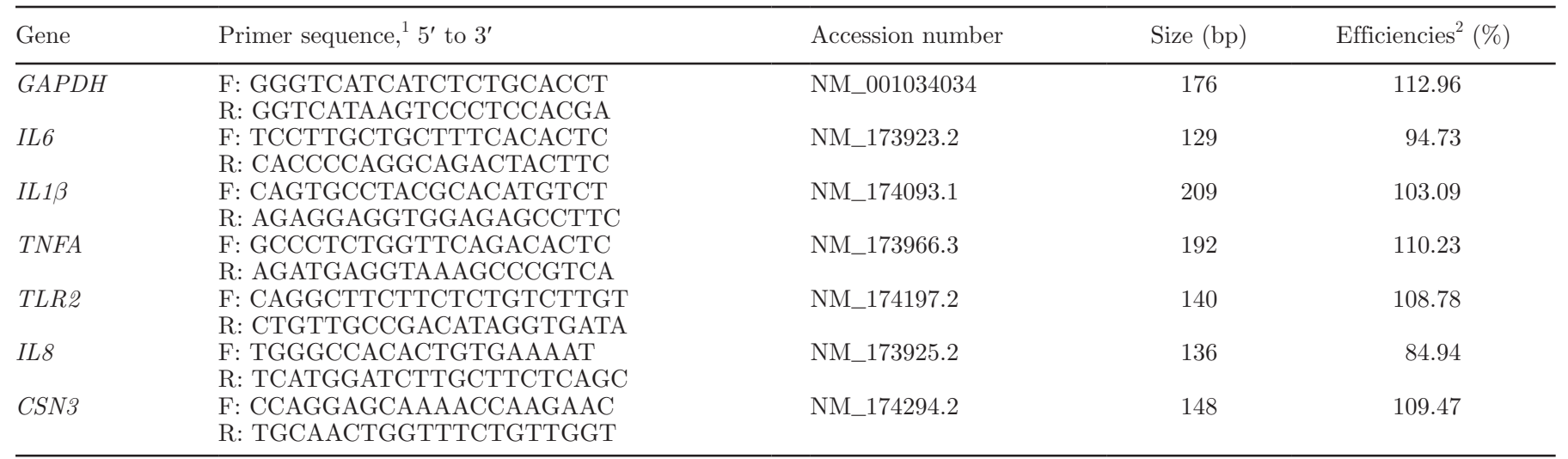

${ }^{1} \mathrm{~F}=$ forward; $\mathrm{R}=$ reverse

${ }^{2}$ Efficiency is calculated as $\left[10^{(-1 / \text { Slope })}-1\right]$.

s. The quantitative (q) RT-PCR assays were performed using SYBR Premix Ex Taq II Kit (Takara). The qRTPCR reaction mixture contained $1 \times$ SYBR Premix Ex Taq II, $0.4 \mu M$ each forward and reverse primers, and $120 \mathrm{ng}$ of cDNA templates in a final volume of 20 $\mu \mathrm{L}$. Reactions were performed as initial denaturation at $95^{\circ} \mathrm{C}$ for $30 \mathrm{~s}$ followed by 40 cycles at $95^{\circ} \mathrm{C}$ for $5 \mathrm{~s}$ and $60^{\circ} \mathrm{C}$ for $30 \mathrm{~s}$. Before qRT-PCR for samples, the amplification efficiencies of all primers were determined by using standard dilution series. The primers used are listed in Table 1. The relative expression of target genes was normalized to that of GAPDH and calculated using the $2^{-\Delta \Delta \mathrm{CT}}$ method.

\section{Statistical Analysis}

All data were presented as means \pm standard error from at least 3 independent experiments. In addition to the results of the invasion, IL-1 $\beta$, IL-6, tumor necrosis factor (TNF)- $\alpha$, and IL-8, all results were distribution of normality and performed by one-way ANOVA, followed by the least significant difference (LSD) for post hoc multiple comparisons of treatment means, using SPSS 19.0 software (SPSS Inc., Chicago, IL). P-values of $<0.05$ were considered significant.

\section{RESULTS}

\section{Assessment of the Cytotoxic Effects of CGA on BMEC}

As shown in Figure 1, the results of cytotoxicity assays demonstrated that treatment with $10 \mu \mathrm{g} / \mathrm{mL}$ CGA enhanced the viability of BMEC compared with the untreated control group $(P=0.047)$. In addition, treatment with $20(P=0.57)$ and $30 \mu \mathrm{g} / \mathrm{mL}(P=0.76)$ of CGA did not exert significant toxic effects on BMEC, whereas $40(P=0.21)$ and $50 \mu \mathrm{g} / \mathrm{mL}(P=0.07)$ of CGA inhibited cell viability compared with controls; however, the differences were not significant.

\section{BMEC Viability After Exposure to S. aureus}

Compared with controls, BMEC exposed to $S$. aureus exhibited $(P=0.002)$ reduced viability (Figure 2$)$. The BMEC exposed to $S$. aureus with 10 or $30 \mu \mathrm{g} / \mathrm{mL}$ CGA treatment enhanced the BMEC viability compared with $S$. aureus treatment alone had not significantly enhanced viability ( $P=0.87$ and 0.14 , respectively). However, the viability of BMEC exposed to $S$. aureus

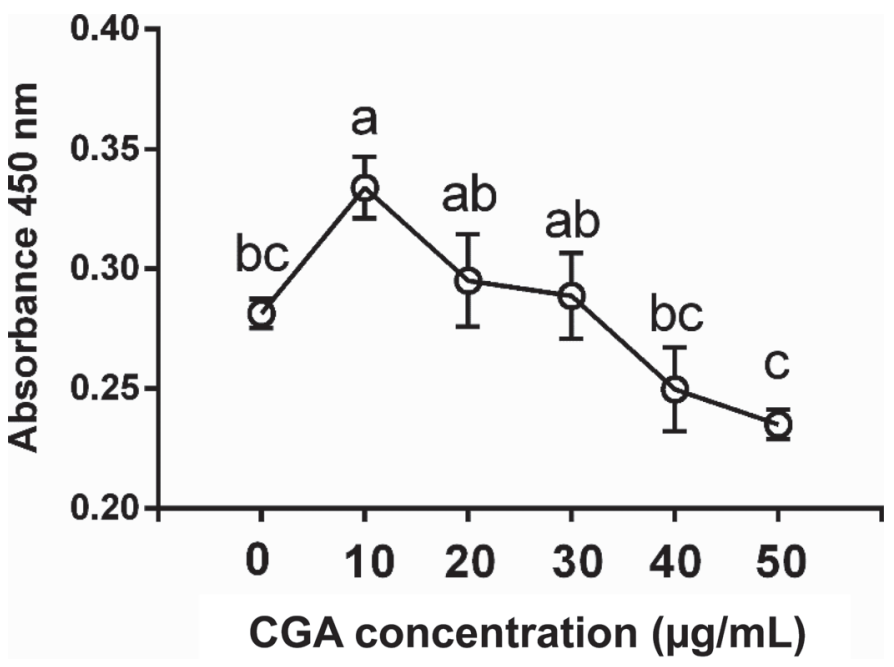

Figure 1. Evaluation of the cytotoxic effects of chlorogenic acid (CGA) on bovine mammary epithelial cells (BMEC) incubated with 0 (control group), 10, 20, 30, 40, or $50 \mu \mathrm{g} / \mathrm{mL}$ CGA. Data are presented as the means \pm SEM $(\mathrm{n}=3)$. Means at the different concentrations of CGA with different letters $(\mathrm{a}-\mathrm{c})$ differ significantly for treatment effect. 


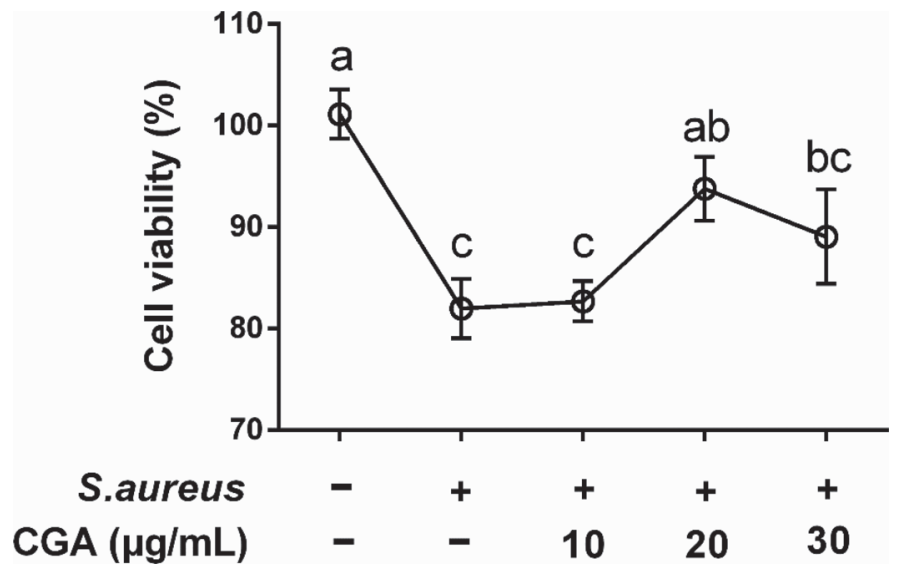

Figure 2. Viability of bovine mammary epithelial cells (BMEC) exposed to Staphylococcus aureus with or without chlorogenic acid (CGA) treatment; BMEC were cultured in DMEM/F12 medium in the absence of $S$. aureus and CGA (control group), in the presence of $S$. aureus and absence of CGA (S. aureus group), and in the presence of $S$. aureus and 10,20 , or $30 \mu \mathrm{g} / \mathrm{mL}$ CGA (CGA-treated groups) for 6 h. Data are presented as the means \pm SEM $(n=3)$. Means at the different treatment groups with different letters $(\mathrm{a}-\mathrm{c})$ differ significantly for treatment effect.

was enhanced $(P=0.03)$ by treatment with $20 \mu \mathrm{g} / \mathrm{mL}$ CGA compared with $S$. aureus alone (Figure 2).

\section{Effect of CGA on S. aureus Growth}

Addition of $20 \mu \mathrm{g} / \mathrm{mL}$ CGA inhibited $S$. aureus growth in $12(P=0.02)$ and $24 \mathrm{~h}(P=0.04)$, compared with the control group (Figure 3 ). Notably, addition of $30 \mu \mathrm{g} / \mathrm{mL}$ CGA inhibited $S$. aureus growth in $9(P=$ $0.03), 12(P=0.01)$, and $24 \mathrm{~h}(P=0.01)$ compared with the untreated control group (Figure 3 ).

\section{Effect of CGA on S. aureus Biofilm Formation}

The $S$. aureus biofilm formation tended to be decreased by addition of $10(P=0.69), 20(P=0.2)$, and $30 \mu \mathrm{g} / \mathrm{mL}(P=0.43)$ of CGA compared with $S$. aureus alone (Figure 4 ).

\section{Effect of CGA on S. aureus Invasion of BMEC}

Compared with controls, the invasion of BMEC by $S$. aureus was not affected by addition of $10(P=0.25)$ and $20 \mu \mathrm{g} / \mathrm{mL}(P=0.21)$ of CGA, whereas at a concentration of $30 \mu \mathrm{g} / \mathrm{mL}$ CGA strongly inhibited $(P=$ 0.004) S. aureus invasion of BMEC (Figure 5).

\section{Effect of CGA on PMNL Chemotaxis}

Pretreatment of PMNL with 10, 20, and $30 \mu \mathrm{g} / \mathrm{mL}$ CGA did not affect their chemotactic ability compared with untreated control groups (Figure 6).

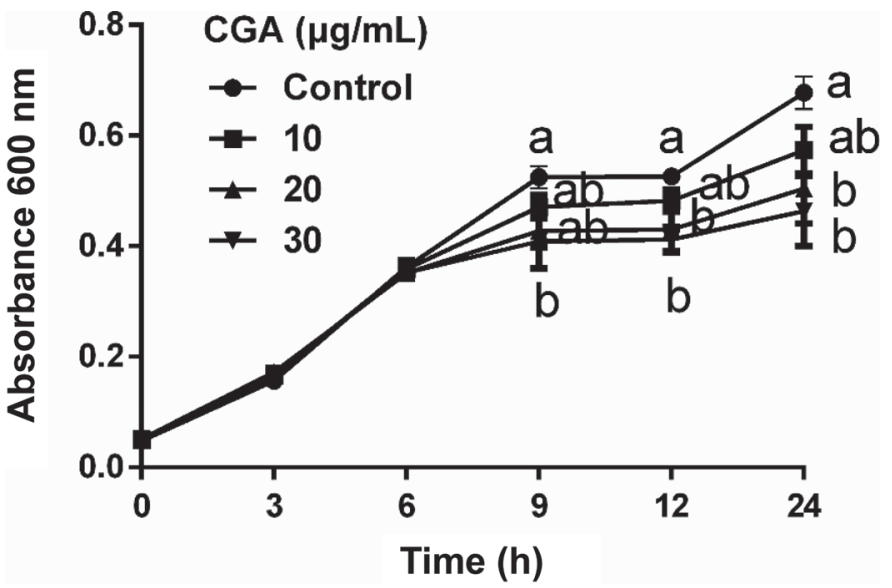

Figure 3. Effect of chlorogenic acid (CGA) on Staphylococcus aureus growth; cultures were incubated with 0 (control group), 10, 20, or $30 \mu \mathrm{g} / \mathrm{mL}$ CGA. Absorbance at $600 \mathrm{~nm}$ was measured after 0,3 , $6,9,12$, and $24 \mathrm{~h}$. Data are presented as the means \pm SEM $(\mathrm{n}=4)$. Means at the same time $(\mathrm{h})$ point with different letters $(\mathrm{a}, \mathrm{b})$ differ significantly for treatment effect.

\section{Effect of CGA on PMNL Phagocytosis}

In comparison with the control group, the treatment of PMNL with $20(P=0.03)$ and $30 \mu \mathrm{g} / \mathrm{mL}(P$ $=0.007)$ of CGA enhanced the phagocytic ability of PMNL compared with the control group (Figure 7).

\section{Effect of CGA on the Inflammatory Response and $\mathrm{k}$-Casein Expression}

The levels of mRNA encoding the cytokines, IL-1 IL-6, IL- 8 , and TNF- $\alpha$, encoding $\kappa$-CN were determined by qRT-PCR. Compared with $S$. aureus treatment alone, addition of $30 \mu \mathrm{g} / \mathrm{mL}$ CGA decreased the levels of mRNA encoding IL-1 $\beta(P=0.73)$, IL-6 $(P=0.57)$,

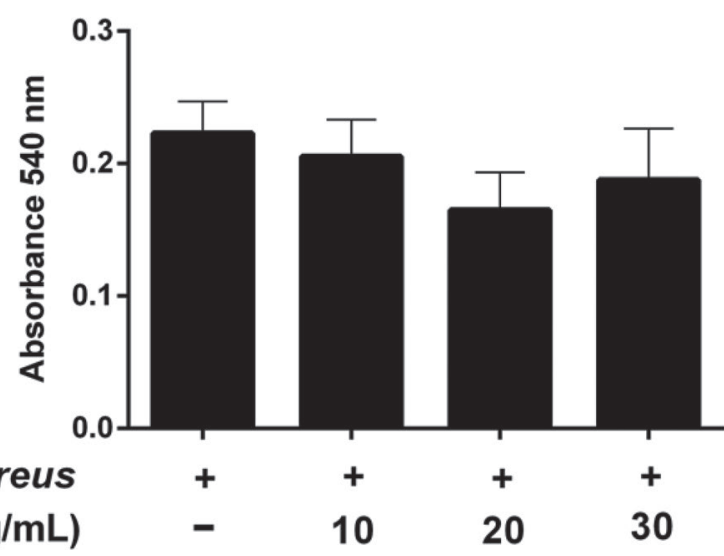

Figure 4. Effect of chlorogenic acid (CGA) on Staphylococcus aureus biofilm formation. The $S$. aureus cultures were incubated with 0 (control group), 10, 20, or $30 \mu \mathrm{g} / \mathrm{mL}$ CGA and absorbance at $540 \mathrm{~nm}$ was measured. Data are presented as the means \pm SEM $(\mathrm{n}=4)$. 


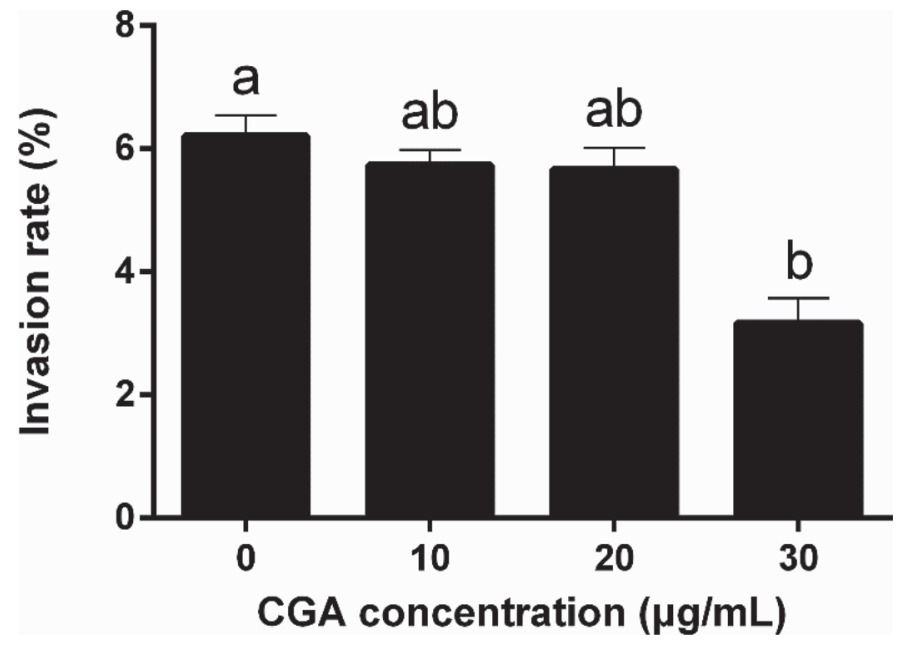

Figure 5. Effect of chlorogenic acid (CGA) on Staphylococcus aureus invasion of bovine mammary epithelial cells (BMEC). The BMEC were incubated in DMEM/F12 medium containing $S$. aureus and 0 (control group), 10, 20, or $30 \mu \mathrm{g} / \mathrm{mL}$ CGA. Data are presented as the means \pm SEM $(n=3)$. Means at the different concentration of CGA with different letters $(a, b)$ differ significantly for treatment effect.

and IL-8 $(P=0.79)$ in $S$. aureus-exposed BMEC (Table 2 ); however, the differences were not significant. Notably, $30 \mu \mathrm{g} / \mathrm{mL}$ CGA strongly decreased $(P=0.001)$ the levels of toll-like receptor- $2 \mathrm{mRNA}$ in $S$. aureusexposed BMEC compared with $S$. aureus treatment alone (Table 2). The chemotactic ability of PMNL in $S$. aureus-exposed BMEC was decreased by adding 10 $(P=0.005)$ and $20 \mu \mathrm{g} / \mathrm{mL}(P=0.02)$ of CGA when BMEC were incubated with $S$. aureus treatment alone (Figure 8). In addition, addition of $30 \mu \mathrm{g} / \mathrm{mL}$ CGA

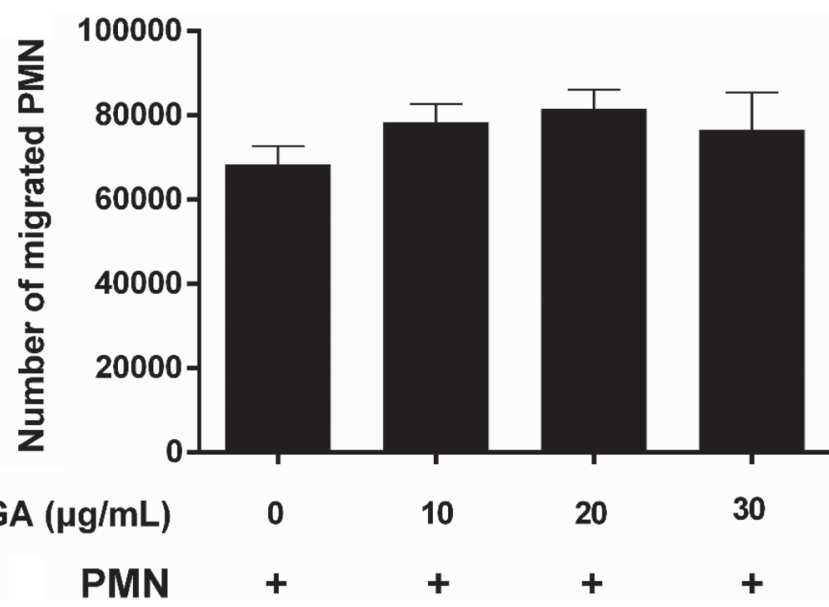

Figure 6. Effect of chlorogenic acid (CGA) on PMNL chemotaxis. Bovine PMNL were pretreated with 0 (control group), 10, 20, or 30 $\mu \mathrm{g} / \mathrm{mL}$ CGA for $2 \mathrm{~h}$, and then the number of migrated PMNL migrating in response to high levels of the chemokine IL-8 were counted. Data are presented as the means \pm SEM $(n=3)$.

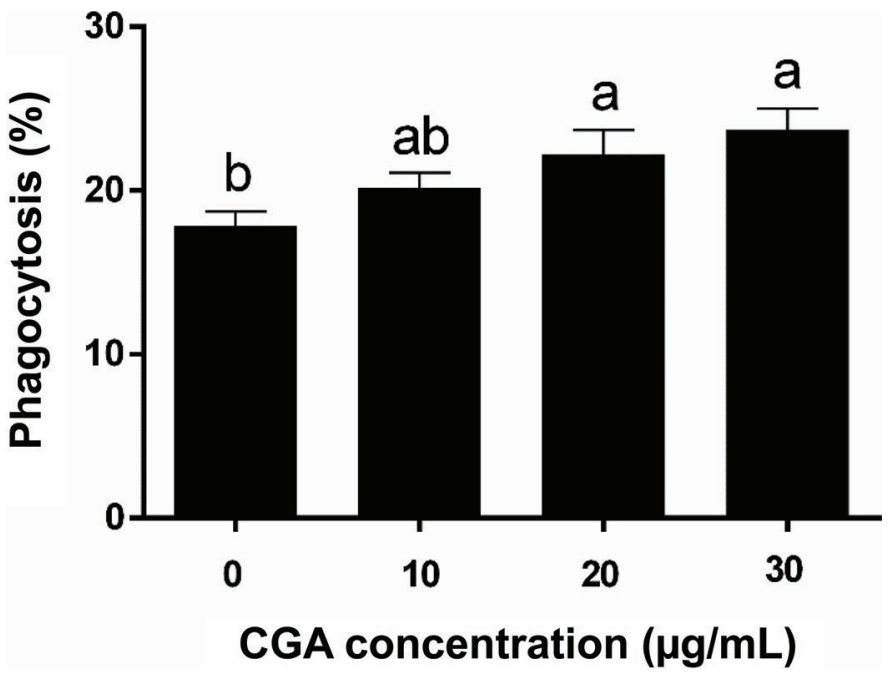

Figure 7. Effect of chlorogenic acid (CGA) on phagocytosis by PMNL. Bovine PMNL were pretreated with 0 (control group), 10, 20, or $30 \mu \mathrm{g} / \mathrm{mL}$ CGA for $2 \mathrm{~h}$, and then Staphylococcus aureus preloaded with fluorescein isothiocyanate $\left(2 \times 10^{5} \mathrm{cfu} /\right.$ well $)$ were incubated with the PMNL for 20 min. Data are presented as the means \pm SEM $(\mathrm{n}=$ 3). Means at the different concentration of CGA with different letters $(a, b)$ differ significantly for treatment effect.

enhanced the abundance of $\kappa-\mathrm{CN}$ mRNA [ $\mathrm{Cq}$ (quantification cycle $)=29.7]$ in $S$. aureus-exposed BMEC when compared with $S$. aureus treatment alone (Table $2)$, although statistical significance was not reached $(P$ $=0.11$ )

\section{DISCUSSION}

Bovine mastitis, an inflammatory response of the mammary gland, is characterized by a mass recruitment of PMNL to local the mammary tissue, triggering a multistep adhesion cascade and defense responses against pathogenic bacterial infection (Sordillo and Streicher, 2002; Mayadas et al., 2014). The BMEC are the first line of defense during pathogen invasion, and are vital in the early response to limit the severity of infections. The BMEC infected with pathogen trigger the release of inflammatory mediators, enhancing the activation of innate immune responses and stimulating the expression of antimicrobial genes (Mitterhuemer et al., 2010); however, these cells can be disrupted during the process of defending against infection, leading to the formation of hard mammary tissue, milk clots, and decreased milk production and quality (Alluwaimi et al., 2003; Bar et al., 2008). Antimicrobial agents are useful for treatment of bovine mastitis caused by $S$. aureus and E. coli; however, such treatment can lead to unwanted residues in milk and bacterial resistance to treatment. Therefore, the development of alternative, novel therapies for bovine mastitis is necessary. 


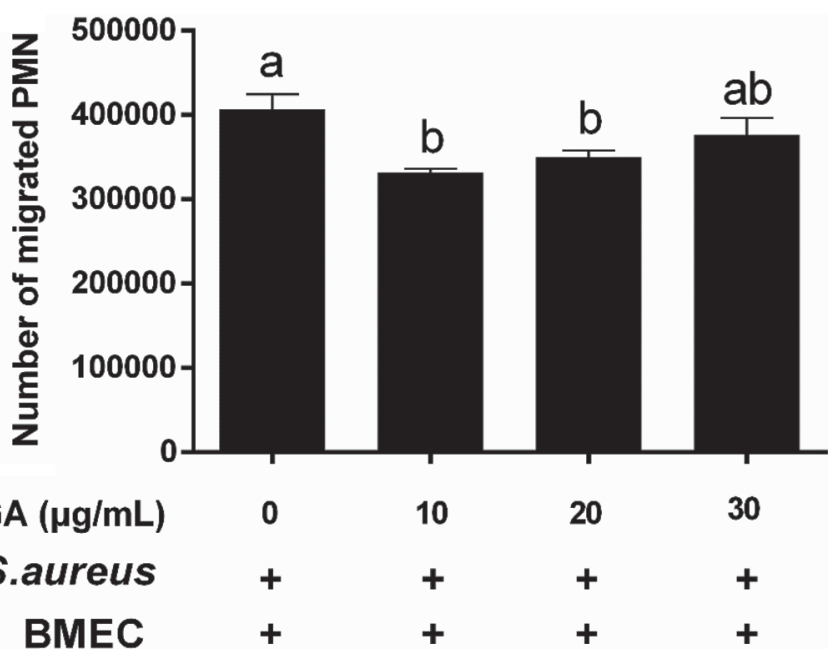

Figure 8. Effect of Staphylococcus aureus-exposed bovine mammary epithelial cells (BMEC) with different concentration of chlorogenic acid (CGA) treatment on PMNL chemotaxis in vitro. The BMEC were incubated with $S$. aureus alone for $6 \mathrm{~h}$ (control group) or with $S$. aureus with addition of 10,20 , or $30 \mu \mathrm{g} / \mathrm{mL}$ CGA for $6 \mathrm{~h}$ (CGA treatment group), and then the number of migrated PMNL migrating in response to different levels of the chemokine IL-8 was counted. Data are presented as the means \pm SEM $(n=3)$. Means at the different concentrations of CGA with different letters (a,b) differ significantly for treatment effect.

Chlorogenic acid has beneficial anti-inflammatory and antimicrobial effects (dos Santos et al., 2006). We demonstrated that CGA is not cytotoxic to BMEC at low doses $(10,20$, and $30 \mu \mathrm{g} / \mathrm{mL})$, and at the lowest dose tested $(10 \mu \mathrm{g} / \mathrm{mL})$ significantly enhanced BMEC viability. These results indicate that CGA does not impair BMEC physiological functions. Furthermore, treatment of BMEC challenged with $S$. aureus with CGA $(20 \mu \mathrm{g} / \mathrm{mL})$ significantly enhanced BMEC viability and, notably, CGA $(30 \mu \mathrm{g} / \mathrm{mL})$ markedly inhibited $S$. aureus growth. These findings are in agreement with those of another study demonstrating that CGA has antimicrobial activity against $S$. aureus and E. coli (Bar et al., 2008). We also evaluated the effect of CGA on $S$. aureus biofilm formation in our study. Staphylococcus aureus biofilms are important in chronic and persistent mastitis infections and can cause bacterial resistance to treatment with antimicrobial agents (Melchior et al., 2006). A previous study demonstrated that CGA could significantly repress biofilm formation in the context of persistent Klebsiella pneumoniae infection (Rajasekharan et al., 2017). Although statistical significance was not reached, our results suggest a trend for the reduction of biofilm with CGA treatment in BMEC cultures challenged with $S$. aureus. Another study demonstrated an inhibitory effect of CGA against Aspergillus fumigatus biofilm formation (Kong et al., 2017). Our results indicate that CGA has the potential role in preventing and controlling biofilm formation strategy in the context of bovine mastitis caused by $S$. aureus.

We also examined the effect of CGA on $S$. aureus invasion of BMEC. The adhesion of $S$. aureus to epithelial cells may involve in nonspecific or specific interactions between bacterial cell-associated ligands and host cell surface receptors, and evidence exists that invasion of mammary epithelial cells by this bacterium may involve an endocytic process requiring binding of bacteria to host cells via surface proteins (Kerro Dego et al., 2002). Persistent mastitis caused by $S$. aureus is a serious problem, which may result from the invasion of mammary epithelial cells by $S$. aureus, as $S$. aureus within cells is protected from antimicrobial agents (Barkema et al., 2006). Our study showed that treatment with CGA $(30 \mu \mathrm{g} / \mathrm{mL})$ significantly inhibited the invasion of BMEC by $S$. aureus, indicating that CGA may contribute to the destruction of extracellular bacteria.

During bovine mastitis, mass recruitment of PMNL to the mammary gland tissue is induced as part of the immune defense response against pathogens; hence, PMNL are a key to the resolution of mastitis. The process of PMNL migration to the bovine mammary gland is often accompanied by the expression of high levels

Table 2. Expression of genes in bovine mammary epithelial cells (BMEC) incubated with 0 (control) or $30 \mu \mathrm{g} / \mathrm{mL}$ chlorogenic acid (CGA) or Staphylococcus aureus or $S$. aureus with $30 \mu \mathrm{g} / \mathrm{mL}$ CGA in vitro

\begin{tabular}{|c|c|c|c|c|c|c|c|}
\hline \multirow[b]{2}{*}{ Symbol } & \multirow[b]{2}{*}{ Gene name } & \multicolumn{4}{|c|}{ Treatment $^{1}$} & \multirow[b]{2}{*}{ SEM } & \multirow[b]{2}{*}{$P$-value } \\
\hline & & Control & CGA & S. aureus & S. aureus with CGA & & \\
\hline TNFA & Tumor necrosis factor- $\alpha$ & $1.01^{\mathrm{ab}}$ & $0.83^{\mathrm{b}}$ & $22.77^{\mathrm{a}}$ & $26.38^{\mathrm{a}}$ & 4.02 & 0.03 \\
\hline IL 8 & Interleukin-8 & $1.02^{\mathrm{b}}$ & $1.28^{\mathrm{b}}$ & $24.18^{\mathrm{a}}$ & $16.29^{\mathrm{ab}}$ & 3.16 & 0.03 \\
\hline TLR2 & Toll-like receptor 2 & $1.03^{\mathrm{b}}$ & $0.98^{\mathrm{b}}$ & $2.56^{\mathrm{a}}$ & $1.39^{\mathrm{b}}$ & 0.20 & 0.001 \\
\hline
\end{tabular}

${ }^{\mathrm{a}-\mathrm{c}}$ Means in the same row with different superscripts differ significantly for treatment effect $(P<0.05)$.

${ }^{1}$ BMEC were cultured in DMEM/F12 medium in the absence of $S$. aureus and CGA (control group), or in the absence of $S$. aureus and presence of CGA (CGA-treated group), or in the presence of $S$. aureus and absence of CGA (S. aureus group), or in the presence of $S$. aureus and $30 \mu \mathrm{g} /$ $\mathrm{mL}$ CGA ( $S$. aureus with CGA treatment group). 
of chemoattractants. In the present study, we observed that the chemotaxis response of bovine PMNL was improved when they were incubated with CGA. This finding suggests that CGA may enhance PMNL chemotaxis, which would be predicted to enhance the rapid immune response against pathogens. Phagocytosis is a fundamental function of PMNL. To date, no studies have examined the effect of CGA on bovine PMNL phagocytosis function. Our data indicate that the addition of CGA (20 or $30 \mu \mathrm{g} / \mathrm{mL}$ ) markedly increased phagocytic killing of pathogens by PMNL.

Host cells infected with pathogens produce a cascade of pro-inflammatory cytokines, including IL-1 $\beta$, IL-6, and TNF- $\alpha$ (Gao et al., 2015), which are key in promoting and regulating the immune response against bacterial pathogens (Lapointe et al., 2010). Interleukin$1 \beta$ and TNF- $\alpha$ are defined as early proinflammatory cytokines (Dinarello, 2000), whereas IL-6 is a third master proinflammatory cytokine and a vital mediator of the acute-phase response in inflammation (Heinrich et al., 2003). Our study demonstrates that CGA can attenuate the expression levels of mRNA encoding IL-1 $\beta$, IL-6, and IL-8 in S. aureus-exposed BMEC; however, the differences were not significant. The downregulation of TNF- $\alpha$ was not observed. In addition, levels of TLR2 mRNA were markedly downregulated in S. aure$u s$-exposed BMEC by adding the CGA. Toll-like receptor 2 principally mediates responses to gram-positive bacteria (Prince et al., 2011) and is crucial in immune responses during $S$. aureus infection. Toll-like receptor 2 is responsible for the regulation of neutrophil functions, including adhesion, generation of reactive oxygen species, release of chemokines, and activation of proinflammatory signaling pathways (Sabroe et al., 2005). Our findings indicate that CGA causes a decrease in proinflammatory cytokines that could relieve inflammatory injury caused by $S$. aureus in bovine mastitis.

To evaluate the safety of CGA for application in bovine in vivo, measurement of casein mRNA level was performed to evaluate the cytotoxic effects of CGA on BMEC. Our results demonstrate that the abundance of k-CN mRNA was downregulated in $S$. aureus-exposed BMEC compared with controls. Notably, addition of CGA $(30 \mu \mathrm{g} / \mathrm{mL})$ enhanced $\kappa$-CN mRNA levels in $S$. aureus-exposed BMEC compared with $S$. aureus treatment alone, but we found no significant differences. The results indicated that dietary supplementation of CGA in cattle may be beneficial for the milk protein synthesis and prophylactic mastitis and be anti-inflammatory. However, subsequent studies must be carried out to determine CGA effects on milk yield, SCC, and cytokine production by the addition of different concentration of CGA to the diet in vivo. Oral administration of CGA to dairy cow may be metabolized by the rumen mi- crobiota; therefore, the rumen-protected CGA product should be used to deliver to the intestinal absorptive sites. These results strongly suggest that CGA has no cytotoxic effects on BMEC and is likely to be safe for in vivo use in cattle.

\section{CONCLUSIONS}

The present study indicates that CGA can relieve the inflammatory responses triggered by $S$. aureus. Furthermore, CGA inhibited $S$. aureus growth and invasion and enhanced the phagocytic ability of PMNL. Importantly, CGA also enhanced the expression levels of $\kappa-\mathrm{CN}$ in $S$. aureus-exposed BMEC. Therefore, CGA should be considered for use as a novel therapy for mastitis caused by $S$. aureus to improve milk production and quality. The effects to CGA and bovine mastitis, including antibacterial, anti-inflammatory, SCC, milk production, and quality, must be evaluated in vivo.

\section{ACKNOWLEDGMENTS}

This study was supported by the National Natural Science Foundation of China (No. 31572430), China Agriculture Research System (CARS-36), Institutes of Agricultural Science and Technology Development (Yangzhou, China); China Joint International Research Laboratory of Agriculture and Agri-Product Safety of Ministry of Education of China (Yangzhou, China).

\section{REFERENCES}

Alluwaimi, A. M., C. M. Leutenegger, T. B. Farver, P. V. Rossitto, W. L. Smith, and J. S. Cullor. 2003. The cytokine markers in Staphylococcus aureus mastitis of bovine mammary gland. J. Vet. Med. B Infect. Dis. Vet. Public Health 50:105-111. https://doi.org/10 .1046/j.1439-0450.2003.00628.x.

Bar, D., L. W. Tauer, G. Bennett, R. N. González, J. A. Hertl, Y. H. Schukken, H. F. Schulte, F. L. Welcome, and Y. T. Gröhn. 2008. The cost of generic clinical mastitis in dairy cows as estimated by using dynamic programming. J. Dairy Sci. 91:2205-2214. https:// doi.org/10.3168/jds.2007-0573.

Barkema, H. W., Y. H. Schukken, and R. N. Zadoks. 2006. Invited review: The role of cow, pathogen, and treatment regimen in the therapeutic success of bovine Staphylococcus aureus mastitis. J. Dairy Sci. 89:1877-1895. https://doi.org/10.3168/jds.S0022 $-0302(06) 72256-1$.

Bhattacharyya, D., J. Banerjee, S. Bandyopadhyay, B. Mondal, P. K. Nanda, I. Samanta, A. Mahanti, A. K. Das, G. Das, P. Dandapat, and S. Bandyopadhyay. 2016. First report on vancomycin-resistant Staphylococcus aureus in bovine and caprine milk. Microb. Drug Resist. 22:675-681. https://doi.org/10.1089/mdr.2015.0330.

Devriese, L. A., L. R. V. Damme, and L. Fameree. 1972. Methicillin (cloxacillin)-resistant Staphylococcus aureus strains isolated from bovine mastitis cases. Zentralbl. Veterinarmed. B. 19:598-605. https://doi.org/10.1111/j.1439-0450.1972.tb00439.x.

Dias, R. S., M. R. Eller, V. S. Duarte, Â. L. Pereira, C. C. Silva, H. C. Mantovani, L. L. Oliveira, A. Silva Ede, and S. O. De Paula. 2013. Use of phages against antibiotic-resistant staphylococcus aureus isolated from bovine mastitis. J. Anim. Sci. 91:3930-3939. https:/ /doi.org/10.2527/jas.2012-5884. 
Díaz-Murillo, V., I. Medina-Estrada, J. E. López-Meza, and A. OchoaZarzosa. 2016. Defensin $\gamma$-thionin from capsicum chinense, has immunomodulatory effects on bovine mammary epithelial cells during Staphylococcus aureus, internalization. Peptides 78:109-118. https://doi.org/10.1016/j.peptides.2016.02.008.

Dinarello, C. A. 2000. Proinflammatory cytokines. Chest 118:503-508.

dos Santos, M. D., M. C. Almeida, N. P. Lopes, and G. E. de Souza. 2006. Evaluation of the anti-inflammatory, analgesic and antipyretic activities of the natural polyphenol chlorogenic acid. Biol. Pharm. Bull. 29:2236-2240. https://doi.org/10.1248/bpb.29.2236.

Federman, C. J. Joo, J. A. Almario, S. Salaheen, and D. Biswas. 2016. Citrus-derived oil inhibits Staphylococcus aureus growth and alters its interactions with bovine mammary cells. J. Dairy Sci. 99:3667-3674. https://doi.org/10.3168/jds.2015-10538.

Gao, J., H. W. Barkema, L. Zhang, G. Liu, Z. Deng, L. Cai, R. Shan, S. Zhang, J. Zou, J. P. Kastelic, and B. Han. 2017. Incidence of clinical mastitis and distribution of pathogens on large chinese dairy farms. J. Dairy Sci. 100:4797-4806. https://doi.org/10.3168/ jds.2016-12334.

Gao, X. J., T. C. Wang, Z. C. Zhang, Y. G. Cao, N. S. Zhang, and M. Y. Guo. 2015. Brazilin plays an anti-inflammatory role with regulating toll-like receptor 2 and tlr 2 downstream pathways in staphylococcus aureus-induced mastitis in mice. Int. Immunopharmacol. 27:130-137. https://doi.org/10.1016/j.intimp.2015.04.043.

Garcia, M., T. H. Elsasser, D. Biswas, and K. M. Moyes. 2015. The effect of citrus-derived oil on bovine blood neutrophil function and gene expression in vitro. J. Dairy Sci. 98:918-926. https://doi.org/ 10.3168/jds.2014-8450.

Graves, S. F., S. D. Kobayashi, and F. R. Deleo. 2010. Communityassociated methicillin-resistant Staphylococcus aureus immune evasion and virulence. J. Mol. Med. (Berl.) 88:109-114. https://doi .org/10.1007/s00109-009-0573-x.

Heinrich, P. C., I. Behrmann, S. Haan, H. M. Hermanns, G. Müllernewen, and F. Schaper. 2003. Principles of interleukin (il)-6type cytokine signalling and its regulation. Biochem. J. 374:1-20. https://doi.org/10.1042/BJ20030407.

Kerro Dego, O., J. E. van Dijk, and H. Nederbragt. 2002. Factors involved in the early pathogenesis of bovine staphylococcus aureus mastitis with emphasis on bacterial adhesion and invasion. a review. Vet. Q. 24:181-198. https://doi.org/10.1080/01652176 2002.9695135

Kim, D. O., S. W. Jeong, and C. Y. Lee. 2003. Antioxidant capacity of phenolic phytochemicals from various cultivars of plums. Food Chem. 81:321-326. https://doi.org/10.1016/S0308-8146(02)00423 -5 .

Kong, J. L., J. Luo, B. Li, B. Y. Dong, H. Huang, K. Wang, L. H. Wu, and Y. Q. Chen. 2017. In vitro activity of chlorogenic acid against Aspergillus fumigatus biofilm and gliotoxin production. Exp. Ther. Med. 13:2637-2644. https://doi.org/10.3892/etm.2017.4317.

Lapointe, S., A. Brkovic, I. Cloutier, J. F. Tanguay, J. P. Arm, and M. G. Sirois. 2010. Group V secreted phospholipase A2 contributes to LPS-induced leukocyte recruitment. J. Cell. Physiol. 224:127-134. https://doi.org/10.1002/jcp.22106.

Li, M., X. Du, A. E. Villaruz, B. A. Diep, D. Wang, Y. Song, Y. Tian, J. Hu, F. Yu, Y. Lu, and M. Otto. 2012. Mrsa epidemic linked to a quickly spreading colonization and virulence determinant. Nat. Med. 18:816-819. https://doi.org/10.1038/nm.2692.

Mayadas, T. N., X. Cullere, and C. A. Lowell. 2014. The multifaceted functions of neutrophils. Annu. Rev. Pathol. 9:181-218. https:// doi.org/10.1146/annurev-pathol-020712-164023.

Medzhitov, R., and C. Janeway Jr. 2000. Innate immunity. N. Engl. J. Med. 343:338-344. https://doi.org/10.1056/ NEJM200008033430506.

Melchior, M. B., H. Vaarkamp, and J. Finkgremmels. 2006. Biofilms: A role in recurrent mastitis infections? Vet. J. 171:398-407. https: //doi.org/10.1016/j.tvjl.2005.01.006.
Mitterhuemer, S., W. Petzl, S. Krebs, D. Mehne, A. Klanner, E. Wolf, H. Zerbe, and H. Blum. 2010. Escherichia coli, infection induces distinct local and systemic transcriptome responses in the mammary gland. BMC Genomics 11:138. https://doi.org/10.1186/1471 -2164-11-138.

Perrone, D., A. Farah, C. M. Donangelo, T. D. Paulis, and P. R. Martin. 2008. Comprehensive analysis of major and minor chlorogenic acids and lactones in economically relevant Brazilian coffee cultivars. Food Chem. 106:859-867. https://doi.org/10.1016/j .foodchem.2007.06.053.

Petzl, W. H. Zerbe, J. Günther, H. M. Seyfert, J. Hussen, and H. J. Schuberth. 2018. Pathogen-specific responses in the bovine udder. Models and immunoprophylactic concepts. Res. Vet. Sci. 116:5561. https://doi.org/10.1016/j.rvsc.2017.12.012 https://dx.doi.

Prince, L. R., M. K. Whyte, I. Sabroe, and L. C. Parker. 2011. The role of TLRS in neutrophil activation. Curr. Opin. Pharmacol. 11:397-403. https://doi.org/10.1016/j.coph.2011.06.007.

Rajasekharan, S. K., S. Ramesh, A. S. Satish, and J. Lee. 2017. Antibiofilm and anti- $\beta$-lactamase activities of burdock root extract and chlorogenic acid against klebsiellapneumoniae. J. Microbiol. Biotechnol. 27:542-551. https://doi.org/10.4014/jmb.1609.09043.

Rice-Evans, C. A., N. J. Miller, and G. Paganga. 1996. Structureantioxidant activity relationships of flavonoids and phenolic acids. Free Radic. Biol. Med. 20:933-956. https://doi.org/10.1016/0891 $-5849(95) 02227-9$

Rooijakkers, S. H., K. P. van Kessel, and J. A. van Strijp. 2005. Staphylococcal innate immune evasion. Trends Microbiol. 13:596-601. https://doi.org/10.1016/j.tim.2005.10.002.

Sabroe, I., S. K. Dower, and M. K. Whyte. 2005. The role of toll-like receptors in the regulation of neutrophil migration, activation, and apoptosis. Clin. Infect. Dis. 41(Suppl 7):S421-S426. https://doi .org/10.1086/431992.

Sato, Y., S. Itagaki, T. Kurokawa, J. Ogura, M. Kobayashi, T. Hirano, M. Sugawara, and K. Iseki. 2011. In vitro, and in vivo, antioxidant properties of chlorogenic acid and caffeic acid. Int. J. Pharm. 403:136-138. https://doi.org/10.1016/j.ijpharm.2010.09.035.

Schukken, Y. H., J. Günther, J. Fitzpatrick, M. C. Fontaine, L. Goetze, O. Holst, J. Leigh, W. Petzl, H. J. Schuberth, A. Sipka, D. G. Smith, R. Quesnell, J. Watts, R. Yancey, H. Zerbe, A. Gurjar, R. N. Zadoks, H. M. Seyfert, and members of the Pfizer mastitis research consortium. 2011. Host-response patterns of intramammary infections in dairy cows. Vet. Immunol. Immunopathol. 144:270289. https://doi.org/10.1016/j.vetimm.2011.08.022.

Sordillo, L. M., and K. L. Streicher. 2002. Mammary gland immunity and mastitis susceptibility. J. Mammary Gland Biol. Neoplasia 7:135-146. https://doi.org/10.1023/A:1020347818725.

Spaan, A. N., B. G. Surewaard, R. Nijland, and J. A. van Strijp. 2013. Neutrophils versus Staphylococcus aureus: A biological tug of war. Annu. Rev. Microbiol. 67:629-650. https://doi.org/10.1146/ annurev-micro-092412-155746.

Thompson-Crispi, K., H. Atalla, F. Miglior, and B. A. Mallard. 2014. Bovine mastitis: Frontiers in immunogenetics. Front. Immunol. 5:493. https://doi.org/10.3389/fimmu.2014.00493.

Wang, H., M. Zhao, B. Yang, Y. Jiang, and G. Rao. 2008. Identification of polyphenols in tobacco leaf and their antioxidant and antimicrobial activities. Food Chem. 107:1399-1406. https://doi.org/ 10.1016/j.foodchem.2007.09.072.

Xu, F., Y. Kang, H. Zhang, Z. Piao, H. Yin, R. Diao, J. Xia, and L. Shi. 2013. Akt1-mediated regulation of macrophage polarization in a murine model of Staphylococcus aureus pulmonary infection. J. Infect. Dis. 208:528-538. https://doi.org/10.1093/infdis/jit177.

Xu, Y., J. Chen, X. Yu, W. Tao, F. Jiang, Z. Yin, and C. Liu. 2010. Protective effects of chlorogenic acid on acute hepatotoxicity induced by lipopolysaccharide in mice. Inflamm. Res. 59:871-877. https://doi.org/10.1007/s00011-010-0199-z. 